\title{
Assessing local people's satisfaction on resettlement arrangements of A Luoi Hydropower project, Thua Thien Hue Province
}

\author{
Đánh giá mức độ hài lòng của người dân về việc bố trí tái định cư của dự án thủy điện A Lưới, \\ Tỉnh Thừa Thiên Huế
}

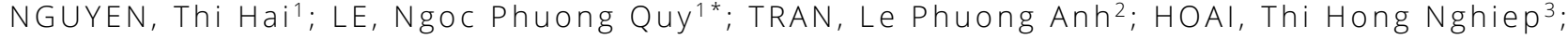 \\ TRAN, Thi Phuong1
} ${ }^{1}$ Hue University of Agriculture and Forestry, Hue University, 102 Phung Hung street, Hue city, Vietnam; 2 School of Hospitality and Tourism, Hue
University, 22 Lam Hoang street, Hue city, Vietnam; ${ }^{3}$ People's Committee of Hong Thuong Commune, A Luoi district, Vietnam

\begin{abstract}
This study aims to estimate the level of satisfaction about resettlement arrangements for local people who have been affected by A Luoi hydroelectric construction project in the Thua Thien Hue province. This research used the Likert scale method to assess the satisfaction level of 98 households living in two of the resettlement sites. Results illustrate that there is variations in the level of satisfaction of local people in the two resettlement sites, Hong Thuong and Hong Ha. In the resettlement area (RA) of the Hong Thuong Commune, people are dissatisfied with the location arrangement. There is a lack of quality in the houses built, been damaged, cracked and degraded, since the construction design is not appropriate for the customs and practices of local people, with a satisfaction rating of 1.07. Meanwhile, at the resettlement site of the Hong $\mathrm{Ha}$ commune, people felt satisfied with the arrangement site of the RA and allocated residential land area with the satisfaction rating of 4.19. Our results will help the government, as well as the project owners, to understand the points of dissatisfaction of local people in order to have accordant solutions, ensuring the stable life for local people in those settlement areas.
\end{abstract}

Nghiên cứu này nhằm mục đích đánh giá được mức độ hài lòng của người dân về việc bố trí tái định cư (TĐC) cho người dân bị ảnh hưởng bởi dự án xây dựng thuỷ điện A Lưới, tỉnh Thửa Thiên Huế. Nghiên cứu đã sử dụng phương pháp thang đo Likert để đánh giá mức độ hài lòng của 98 hộ dân sống tại hai khu tái định cư Hồng Thượng và Hồng Hạ. Kết quả nghiên cứu đã cho thấy có sự khác nhau về mức độ hài lòng của người dân tại hai khu TĐC. Tại khu TĐC Hồng Thượng người dân thấy không hài lòng về địa điểm bố trí $T \bigoplus C$, nhà ở được xây dựng thiếu chất lượng đã bị hư hỏng, nứt nẻ xuống cấp, thiết kế xây dựng không phù hợp với phong tục, tập quán của người dân địa phương, với chỉ số đánh giá hài lòng là 1,07. Trong khi đó, tại khu TĐC xã Hồng Ha người dân lại thấy hài lòng về điểm bố trí TEC và diện tích đất ở được cấp, với chi số đánh giá hài lòng là 4,19. Kết quả nghiên cứu của đề tài sẽ giúp cho chính quyền cũng như chủ đầu tư dự án nắm rõ những điểm không hài lòng của người dân để có hướng giải quyết phù hợp nhằm đảm bảo cuộc sống ổn định cho người dân tại nơi tái định cư.

Keywords: A Luoi hydropower plant, local people's satisfaction, resettlement arrangement

\section{Introduction}

Along with economic benefits, the construction of hydropower projects has often strongly impacted local communities due to migration and resettlement (Thanh, 2018). These communities are mainly ethnic minorities with a long-standing culture, but their production and living activities are still difficult and limited. Relocation has made the lives of people in resettlement areas (RAs) more volatile. The reason is that these are people who have lost their inherent assets, lifestyles and production practices to move to a new environment with new production conditions, new culture, and new communities (Hao,
2015). The research of Nguyen \& Hanh (2012) on the quality of life of Song Tranh 2 hydropower RAs in the Quang Nam province, has shown that most of resettled people are poor to confront many obstacles in approaching land; the land is in poor quality and people do not have stable jobs, often with low incomes. Similarly, resettled people due to the Ban Ve hydropower project in the Nghe An province, also face the problem of lack of productive land, dwelling and other infrastructures seriously degraded after 10 years of resettlement (Anh, 2019). According to a research performed by the The Consultancy on Development (CODE) (2010), the RAs are allocated in difficult locations, with no conditions for agricultural development and lack of non-agricultural job 
opportunities. Therefore, good planning for resettlement plays a vital role in reducing risks and improving the quality of life for resettled people (IOM, 2017). In addition, during the implementation process, the government needs coordination with the investor to regularly inspect, maintain and improve the quality of infrastructure in the RA. At the same time, care and support for the production development and livelihood improvement for resettled people also need to be regularly implemented (MOIT, 2016).

A Luoi is a mountainous district in the west of the Thua Thien Hue province. With favorable natural conditions for hydropower development, the district was selected to invest in the development of A Luoi hydropower station, a large-scale project in the Thua Thien Hue province. The A Luoi hydropower project was surveyed in 2007, having carried out the migration, compensation and site clearance from 2010. To ensure space for the construction of the A Luoi hydropower station, the project had to move 285 households from 7 communes of the A Luoi district to be resettled in Hong Thuong and Hong Ha communes.

The resettlement of the project was accomplished in 2015, however, the lives of resettled people still have some issues that need the attention (Thua Thien Hue PPC, 2008). In the history of the RA in Thua Thien Hue, the majority of affected people lack of land for their livelihoods. Furthermore, the soil is not suitable for a high crop productivity. Many ethnic minorities are gradually losing their cultural identity, meaning that their spiritual life is gradually lost (Department of Science and Technology of Thua Thien Hue, 2010).

The success of the project was estimated by the satisfaction of the resettled people. This study aims to analyze local people's satisfaction in resettlement sites in order to avoid the aforementioned mistakes during the A Luoi hydropower resettlement activity. Our results will be beneficial in proposing recommendations and measures to improve the satisfaction of people in the resettlement sites of the A Luoi hydropower project in the Thua Thien Hue province.

\section{Research methodology}

\subsection{Methods of data collection, secondary data}

The study collected relevant data and documents about the investigated area such as information of affected objects and reports on the A Luoi hydropower project. Data was collected from the Department of Natural Resources and Environment, the A Luoi District Land Fund Development Center and the People's Committees of Hong Thuong and Hong Ha communes.

\subsection{Questionnaire survey method}

To assess the satisfaction level of people living in the RA of the A Luoi hydropower project in Hong Thuong and Hong $\mathrm{Ha}$ communes. For the resettlement layout of the A Luoi hydropower project, this study has utilized 5-point Likert scale, from 1 - very dissatisfied to 5 - very satisfied. To determine the minimum and the maximum length of the five-point Likert type scale, the range is calculated by the following formula

$$
\mathrm{n}=\frac{\text { maximum }- \text { minimum }}{\text { maximum }}=\frac{5-1}{5}=0.8
$$

Regarding the RA of the A Luoi hydropower project, the level of local people's satisfaction about key factors is determined on the following scale: $n>=4.2$ : very satisfied; $3.4 \leq n \leq 4.19$ : satisfied; $2.6 \leq n \leq 3.39$ : neutral; $1.8 \leq n \leq 2.59$ : dissatisfied; $n<1.8$ : very dissatisfied.

Using the Slovin formula, the number of interviewed households, living in resettlement sites in Hong Thuong and Hong Ha communes of the A Luoi district, Thua Thien Hue province, was estimated according:

$$
\mathrm{n}=\frac{N}{1+N \cdot e^{2}}=\frac{285}{1+285 * 0.1^{2}}=98
$$

Where $\mathrm{n}$ is the sample size; $\mathrm{N}$ is the population size; e: level of precision (10\%). The resettlement of the A Luoi hydropower project has been carried out in two resettlement sites (Hong Thuong commune and Hong $\mathrm{Ha}$ commune), therefore, to ensure the accuracy of the survey results, the number of households interviewed for the study was distributed at each RA as shown in Table 1.

Table 1 . Statistics of number of resettled households and number of interviewed households of A Luoi hydropower project
\begin{tabular}{llll} 
No & Name of the Ras & Number of resettled households & Number of interviewed households \\
\hline 1 & RA in Hong Ha commune & 26 & 26 \\
2 & RA in Hong Thuong commune & 259 & 72 \\
Total & 285 & 98 \\
\hline
\end{tabular}




\section{Research results}

\subsection{A Luoi Hydropower Project and affected objects by project}

The A Luoi hydropower plant is located on the A Sap River in the A Luoi district, Thua Thien Hue province. It is located at $70 \mathrm{~km}$ from the center of Hue city (along Highway 49 to the West) and $90 \mathrm{~km}$ from Lao Bao Border Gate to the South (along the Truong Son road, Highway 14). The A Luoi hydropower project lies in 7 communes of the A Luoi district, including Hong Ha, Phu Vinh, Hong Thuong, Son Thuy, Hong Thai, Hong Quang and Nham communes.
The construction of the A Luoi hydropower project has influenced 29 organizations and 1,583 households in 7 communes of the A Luoi district (Table 2). From the 1,583 affected households, affected by the A Luoi hydropower construction project, 285 households (1,364 inhabitants) have been relocated. These households encompass 5 ethnic groups, including Kinh, Muong, $\mathrm{Pa} \mathrm{CO}, \mathrm{Ta} \mathrm{Oi}$ and $\mathrm{Ka}$ Tu. These groups lived in the reservoir area of the project in 7 communes including Phu Vinh, Hong Thuong, Son Thuy, Hong Thai, Hong Quang, Hong Ha and Nham. The communes of Hong Thuong, Son Thuy, Hong Thai, Hong Ha have the largest number of relocated households, oscillating from 26 to118 households. Communes of Phu Vinh, Hong Quang and Nham have a smaller number of households to relocate only about 2 or 3 households/communes.

Table 2. Statistics of affected objects of A Luoi hydropower project

\begin{tabular}{llll} 
No & Content & Unit & Quantity \\
\hline 1 & Number of affected households & households & 1,583 \\
2 & Number of relocated households & households & 285 \\
3 & Number of people who have to be relocated & people & 1364 \\
4 & Affected area & ha & 1,908 \\
\hline
\end{tabular}

Source: Thua Thien Hue Provincial People's Committee, 2008

In the 1,907 ha of land affected by the A Luoi hydropower project, there are 1,142 ha of acquired land, located in 7 communes including Hong Thuong, Hong Ha, Phu Vinh, Son Thuy, Hong Thai, Hong Quang and Nham communes in the A Luoi district. Included in the total land, acquired for the project implementation, there are 62.26 ha of residential land (accounting for 5.45\%); 731.6 ha of arable land (making up to 64.04\%); 260.6 ha of forest land (occupying 22.82\%) and 88.04 ha of special use land (accounting for 7.7\%). The structure of land acquisition of the project is shown in Figure 1.

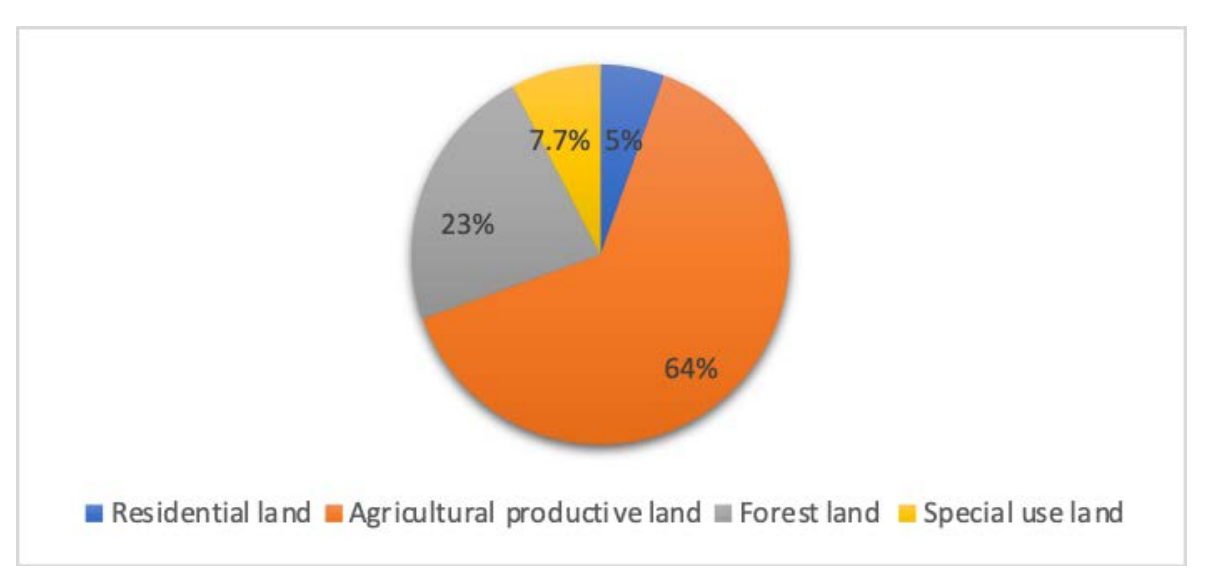

Figure 1. Structure of land acquisition for A Luoi hydropower construction

\subsection{Assessment of local people's satisfaction with resettlement arrangement in Hong Thuong and Hong Ha communes}

\subsubsection{Evaluating the satisfaction level on location, topography and land of the two Ras}

The construction of the A Luoi hydropower plant have displaced 285 households located in the project's affected area. To ensure the stability of accommodation and living for these households, the project built two RAs, one in the
Hong Thuong commune and other in the Hong $\mathrm{Ha}$ commune, both in the A Luoi district. The RA in Hong Thuong commune has an extension of 247 ha, located in A Den hamlet and A Xap hamlet (formerly Kon Tom hamlet). This RA is 1,500 $\mathrm{m}$ far from the Ho Chi Minh Road and about $6 \mathrm{~km}$ far from the commune center. The topography of this RA includes two types: low hills and plain terrains which includes a small area which is suitable for agricultural production and residence. The high mountain terrain, with an altitude of approximately $600 \mathrm{~m}$, has great potential for forestry development but it faces 
many difficulties due to the underdeveloped transport infrastructure. The land area of this RA was planned mainly from forest land, consisting 85.5 ha (34.6\%) of planted forest land, 58.4 ha (23.6\%) of natural forest land, 15.0 ha (6.1\%) of unused land, 32.7 ha (13.2\%) of perennial cropland and 55.4 ha (22.4\%) of other land types. The RA in the Hong $\mathrm{Ha}$ commune has an area of 6.6 ha and is distributed in the A Rom hamlet. This is about $2.5 \mathrm{~km}$ far from Highway 49, about $8 \mathrm{~km}$ away from the commune center. The topography of this RA is quite flat with a small area appropriate for agricultural production. Survey results on the level of local people's satisfaction with the resettlement location of the RAs in the Hong Thuong and Hong $\mathrm{Ha}$ communes ae not similar. Detailed data are shown in Table 3.

\section{Table 3. Results of the survey on local people's satisfaction about resettlement location}

\begin{tabular}{llll} 
No & Name of resettlement site & Mean & Satisfaction level \\
\hline 1 & RA in Hong Ha Commune & 4.19 & Satisfied \\
2 & RA in Hong Thuong Commune & 1.07 & Dissatisfied \\
\hline
\end{tabular}

Source: Household interview data, 2020

Data displayed in Table 3 shows the interview results of this study. It illustrates that households in the RA located in the Hong $\mathrm{Ha}$ commune are satisfied with the resettlement site, a mean of 4.19 on the Likert scale. Results from the resettlement site of the Hong $\mathrm{Ha}$ commune are driven by the flat land, favorable land for housing and gardening. On the other hand, the Likert scale mean is only 1.07 in the RA of Hong Thuong commune. This shows that local people were dissatisfied with the resettlement location. The main reason is the bad and uneven land, under risk of flooding and easily isolated during the rainy season given its proximity to the A Sap River. Other reasons are the damage presented by houses and building (Fig. 2). Additionally, there are bomb craters around, it is far from the commune center and the Ho Chi Minh Road and close to wild forests and mountains.

\subsubsection{Evaluating the satisfaction level on infrastructure of the two resettlement sites}

The RA of the A Luoi hydropower project in the Hong Thuong commune was built in 2007. According to the Decision No. 526/QD-UBND on March $3^{\text {rd }}$ 2008, the Thua Thien Hue Provincial People's Committee approved the project. The approval relied on the investor commitment to build infrastructure including systems for traffic roads, medium and low-voltage power, drainage, domestic water supply, irrigation, housing, kindergartens, primary schools, secondary schools, meeting houses, medical offices, markets, sports courts and cemeteries for the RA. By 2019, after 12 years of construction, the RA infrastructure owned many work items. Presently, the RA of Hong Thuong commune has 10 projects implemented and 3 projects have not yet been, built including markets, sport field and cemeteries (detailed in table 4).

\section{Table 4. Current situation of infrastructure system of RA in Hong Thuong commune}

\begin{tabular}{|c|c|c|c|c|c|c|}
\hline \multicolumn{2}{|c|}{ NoName of works } & \multirow{2}{*}{$\begin{array}{l}\text { Unit } \\
\mathrm{km}\end{array}$} & \multicolumn{2}{|c|}{$\begin{array}{l}\text { QuantityYear of } \\
\text { construction }\end{array}$} & Note & Status \\
\hline 1 & Traffic road & & 5 & 2010 & $\begin{array}{l}\text { Roads have a width of } 3 \mathrm{~m} \text { and being } \\
\text { concreted }\end{array}$ & $\begin{array}{l}\text { Some roads are damaged and } \\
\text { degraded }\end{array}$ \\
\hline 2 & Electricity system & $\mathrm{Km}$ & 2 & 2010 & $\begin{array}{l}\text { Electricity reaches households and there } \\
\text { have been lighting systems along the } \\
\text { roads }\end{array}$ & $\begin{array}{l}\text { Serving } 100 \% \text { of the needs of living } \\
\text { activities }\end{array}$ \\
\hline 3 & $\begin{array}{l}\text { Domestic water } \\
\text { supply system }\end{array}$ & $\mathrm{km}$ & 2.5 & 2010 & Waterpipes reach to each household & Renovated in 2015 \\
\hline 4 & Drainage System & $\mathrm{km}$ & 2.5 & 2010 & The sewer lines are made of concrete & Normal operation \\
\hline 5 & Housing & house & 259 & 2010 & $\begin{array}{l}\text { Built in Level } 4 \text { with the corrugated iron } \\
\text { roof }\end{array}$ & Some houses are degraded \\
\hline 6 & Kindergarten & school & & 2010 & 3 rooms/48m2/room & Lack of concrete yard and fences \\
\hline 7 & Primary School & school & & 2010 & 5 rooms/48m2/room & Lack of concrete yard and fences \\
\hline 8 & High school & school & & 2010 & $5 \mathrm{rooms} / 48 \mathrm{~m} 2 / \mathrm{room}$ & $\begin{array}{l}\text { Unused rooms because they were } \\
\text { handed over to A Luoi district's } \\
\text { Association of the Blind }\end{array}$ \\
\hline 9 & $\begin{array}{l}\text { Village meeting } \\
\text { house }\end{array}$ & house & 03 & 2010 & House built and roofing & $\begin{array}{l}\text { New construction to meet the } \\
\text { standards in } 2017\end{array}$ \\
\hline & Medical office & office & 1 & 2010 & House built and roofing & Closed since 2015 \\
\hline & Market & market & & & Not built yet & \\
\hline & Sports court & court & 0 & & Not built yet & \\
\hline & Cemetery & zone & 0 & & Not built yet & \\
\hline
\end{tabular}




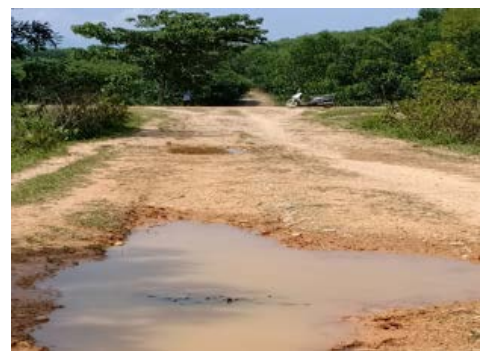

Damaged and degraded roads.

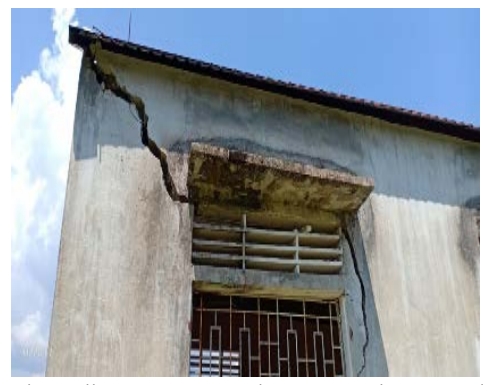

The village meeting house is damaged, cracked and unusable.

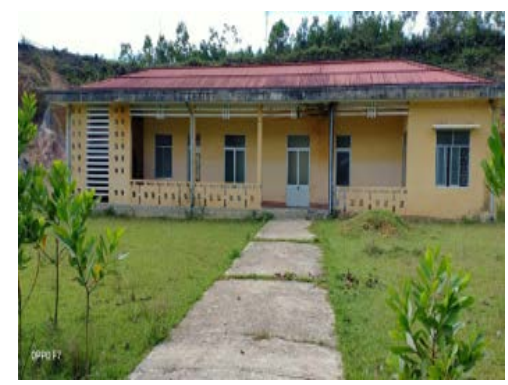

The medical office has not been put into use

\section{Figure 2. Pictures of RA in Hong Thuong commune}

Source: Thua Thien Hue provincial People's Committee and field survey data

The survey also shows that currently, the RA infrastructure in the Hong Thuong commune such as roads, schools, offices and village meeting houses, are damaged, degraded and do not put into use. Facilities such as markets, sports courts and graveyards have not been constructed yet as the plan approved by the competent authority. This causes a lot of frustration among local people, leading to many obstacles for travelling and business exchange, creating great difficulties for the life and economic development of each family and locality. Therefore, the current general situation is that many households had sold their land and houses to live elsewhere. Besides, people in this RA have differences in ethnicity, language and religion, making difficult their integration with the community. The RA of Hong $\mathrm{Ha}$ commune was built in 2014. According to Decision No. 1821/QD-UBND on September 28, 2010, the Thua Thien Hue Provincial People's Committee approved the project, the RA was committed to build infrastructure systems similar to those proposed for the Hong Thuong commune. In 2019, after 5 years of construction, the infrastructure of the RA had many work items (detailed in Table 5).

Table 5. Current situation of Infrastructure system of the RA in Hong Ha commune

\begin{tabular}{|c|c|c|c|c|c|c|}
\hline No & Name of works & Unit & Quantity & $\begin{array}{l}\text { Year } \\
\text { construction }\end{array}$ & Note & Status \\
\hline 1 & Kindergarten & kindergarten & 1 & 2014 & $\begin{array}{l}\text { House built with the } \\
\text { corrugated iron roof }\end{array}$ & Normal operation \\
\hline 2 & Electricity system & $\mathrm{km}$ & 3,158 & 2014 & $\begin{array}{l}\text { Power lines reach } \\
\text { households and there } \\
\text { have been lighting } \\
\text { systems along the main } \\
\text { road of the hamlet }\end{array}$ & Normal operation \\
\hline 3 & $\begin{array}{l}\text { Domestic water } \\
\text { supply system }\end{array}$ & $\mathrm{km}$ & 1.50 & 2014 & $\begin{array}{l}\text { water pipes reach to } \\
\text { households }\end{array}$ & Normal operation \\
\hline 4 & Housing & house & 26 & 2014 & $\begin{array}{l}\text { Wooden houses, } \\
\text { temporary houses, } \\
\text { houses built }\end{array}$ & $\begin{array}{l}\text { Solidly built houses } \\
\text { accounting for less } \\
\text { than } 15 \%\end{array}$ \\
\hline 5 & Traffic road & $\mathrm{km}$ & 1,0 & 2016 & $\begin{array}{l}\text { Concreting with road } \\
\text { width of } 4 \mathrm{~m}\end{array}$ & Normal operation \\
\hline 6 & $\begin{array}{l}\text { Village meeting } \\
\text { house }\end{array}$ & house & 0 & - & Not built yet & - \\
\hline 7 & Sports court & court & 0 & - & Not built yet & - \\
\hline
\end{tabular}

Source: Thua Thien Hue provincial People's Committee and field survey data

In general, after local people were resettled in these RAs, the roads are convenient and the infrastructures are fully equipped, but this is still a deserted and new place, new neighbors are not friendly. Besides, it is also far from the center of the commune, isolated from other residential areas of the commune; trading services are still sparse, the land is lacking, driving some people to return to their old place to work in cultivation. 
Table 6. Survey results on the level of local people's satisfaction with the infrastructure system of the RA

\begin{tabular}{llll} 
No & Name of the resettlement site & Mean & Satisfaction level \\
\hline 1 & RA of Hong Ha Commune & 1.07 & Dissatisfied \\
2 & RA of Hong Thuong Commune & 1.1 & Dissatisfied \\
\hline
\end{tabular}

2 RA of Hong Thuong Commune

$1.1 \quad$ Dissatisfied

Source: Household interview data, 2020

The data in Table 6 demonstrates that, at the RA of Hong $\mathrm{Ha}$ commune, the evaluation towards the infrastructure system from households reach the mean of 1.07 on the Liert scale, proving that local people are not satisfied with this issue. The reason is that many internal roads have been seriously damaged, lack of village meeting houses, medical offices, schools, irrigation systems etc. In the RA of Hong Thuong commune, the mean on the Likert scale is 1.1, showing that local people are also dissatisfied with the infrastructure system of RA. Specifically, 65 out of 72 interviewed households said that they were dissatisfied with the infrastructure here. The reason is that the RA in Hong Thuong commune still lacks high schools, sports courts, markets and clinics; at the same time, other works of this RA are also damaged and deteriorated, which is not able to ensure to meet local people's needs of living activities.

\subsubsection{Assessing the satisfaction level on residential land allocated of the two resettlement sites}

To ensure the stable accommodation for households displaced due to the acquisition of land for the A Luoi hydropower project, households were allocated in residential land of the RAs of Hong Thuong and Hong $\mathrm{Ha}$ communes (Table 7).

\section{Table 7. The situation of residential land allocation for households in RAs}

\begin{tabular}{|c|c|c|c|c|}
\hline No & Target & Unit & $\begin{array}{l}\text { RA in Hong Thuong } \\
\text { commune }\end{array}$ & $\begin{array}{l}\text { RA in Hong } \mathrm{Ha} \\
\text { commune }\end{array}$ \\
\hline 1 & Number of households are allocated land & household & 259 & 26 \\
\hline 2 & Area of residential land allocated to a household & m2/household & 500 & 500 \\
\hline 3 & Forms of allocation & - & Pick at random & Pick at random \\
\hline
\end{tabular}

Source: Thua Thien Hue PPC, 2008

Table 7 indicates that households displaced due to the influence of the A Luoi hydropower project were allotted residential land. The area of residential land allocated to each household in each resettlement site was equal to 500 $\mathrm{m}^{2}$ per household. Land allocation in both RAs was carried out by random picking of households. After the distribution of residential land in RA, its area had changed compared to the area before the resettlement. This is illustrated in Table 8.

\section{Table 8. The average residential land area of households before and after being resettled}

\begin{tabular}{lllll} 
No & RA & Before resettlement & After resettlement & Increase $(+) /$ Decrease $(-)$ \\
\hline 1 & RA of Hong Thuong commune & 2000 & 500 & -1500 \\
2 & RA of Hong Ha commune & 0 & 500 & +500 \\
\hline
\end{tabular}

Source: Thua Thien Hue PPC, 2008 (unit: $\mathrm{m}^{2} /$ household)

It can be seen from table 8 that after being arranged to resettle, the residential land area of households in each RA was different. Specifically, 259 households in the RA of the Hong Thuong commune had a less allocated area than their former residence. The reason is that in the old residence, the households had exploited the land and lived there for many generations, so they had a large area of residential land. After their land is acquired and arranged for resettlement in RA of Hong Thuong commune, these households are assigned residential land according to the rule of the residential land norm for the A Luoi district.

Unlike the RA in Hong Thuong commune, 26 households resettled in the Hong $\mathrm{Ha}$ commune had a larger area of allocated residential land at RA than at the old dwelling. The reason is that these households, living with other ones (secondary households) within the land acquisition scope of the A Luoi hydropower project, do not have residential land in their former residence. Under the influence of the project, they had been distributed residential land to live independently in the RA of Hong Ha commune.

Regarding the allocation of residential land, this brought certain advantages but difficulties in life as well as the economic development to the households in the two RA. In detail, the Hong Thuong resettled households are those who had completely acquired residential land for resettlement in a new place, with the allocated land area of $500 \mathrm{~m}^{2}$ /household that was only enough to build houses and ancillary works. They did not have much area to make barns for breeding and farming, which caused difficulties in the production organization of local people, affecting the 
lives and economic development of households. Meanwhile, the Hong $\mathrm{Ha}$ resettled households are the ones who do not have residential land in their old place, with the allocated land area of $500 \mathrm{~m}^{2} /$ household, they had land for housing and a part of the area for building barns, raising and growing crops to improve their living and economic development.
The distribution of residential land to displaced households of the A Luoi hydropower project had been done by random picking on the same equal area of $500 \mathrm{~m}^{2}$. The allocated area is sufficient for housing construction and essential ancillary works. However, the results of the survey on local people's satisfaction with residential land allocated in the two RA were not the same. The figures are shown in Table 9.

Table 9. Results of the survey on local people's satisfaction with the allocated residential land in the RA

\begin{tabular}{llll} 
No & Name of RA & Mean & Satisfaction level \\
\hline 1 & RA in Hong Ha commune & 4.5 & Very satisfied \\
2 & RA in Hong Thuong Commune & 1.23 & Dissatisfied \\
\hline
\end{tabular}

Source: Household interview data, 2020

It is obvious from table 9 that at the RA of Hong $\mathrm{Ha}$ commune, local people are very satisfied with the area of residential land allocated for resettlement with a mean of 4.5. The reason is that 26 households, before being assigned to the RA in the Hong $\mathrm{Ha}$ commune, are all households without residential land, they shared the house with their parents, brothers or some of them build temporary houses on borrowed land from their relatives. Therefore, when being granted $500 \mathrm{~m}^{2}$ of land, they have utilized a part of the area to build houses and the rest of the area to build breeding facilities and to grow crops, improving their lives developing the household economy. Unlike local people in RA of the Hong Ha commune, households in the RA of the Hong Thuong commune were not satisfied with the allocated residential land (mean of only 1.23). The reason is that these households had stable land in their old place. To build the A Luoi hydropower project, they had to return their land to the government and were also directly affected by land acquisition, houses and assets attached to their former land. However, when being arranged to live in the RA, some households had less residential land allocated to them than the old one; others had uneven grounds, soils are too bad and discolored, they are rocky, low-lying with bomb craters so they are inundated in the rainy season. These reasons led to 65 out of 72 surveyed households assessing that they were dissatisfied with the allocated residential land.

\subsubsection{Assessment of the satisfaction level of productive land allocated to the two RAs}

The current situation of allocated productive land to resettled households affected by the A Luoi hydropower project is shown in Table 10.

\section{Table 10. Productive land allocation to households in the RAs}

\begin{tabular}{llll} 
No & Target & RA of Hong Thuong commune & RA of Hong Ha commune \\
\hline 1 & $\begin{array}{l}\text { The area of productive land allocated to one household } \\
\text { (m2/household) }\end{array}$ & $500-2000$ & Not available \\
2 & Number of allocated households (household) & 259 & Not available \\
3 & Forms of allocation & Picking the location at random & Not available \\
\hline
\end{tabular}

Source: Thua Thien Hue Provincial People's Committee, 2008

Table 10 illustrates that the allocation of productive land to resettled households was only carried out in the RA of the Hong Thuong commune. In this commune, there are 151.76 ha of protected forest land which was handed over by the A Luoi district to the People's Committee of the Hong Ha commune for management. The commune had developed a plan to allocate land to resettlement households and households who did not have productive land. However, in the official dispatch No. 3362017 of the Department of Agriculture and Rural Development of the Thua Thien Hue province, land allocation and suspension of land allocation to households have not yet allowed. Hence, in the RA of the Hong Ha commune, local people had not yet been allocated with productive land. Having no productive land, the life of 26 relocated households in the Hong Ha commune faces many obstacles. Their main source of income is only from a day-to-day employment. Unlike the RA of the Hong Ha commune, in the RA of the Hong Thuong commune, all of the 259 households were allotted land for production with the lowest household area of $500 \mathrm{~m}^{2}$ and the highest area of 2,000 $\mathrm{m}^{2}$. This difference derives from the specific productive land allocated to each household, determined based on the converted area of productive land in the former residence of each household.

Land types allocated to resettlement households in Hong Thuong commune were mainly land for other annual crops and rice cultivation. The allocation of productive land in RA had been done by picking at random and then assigning to households in the converted area compared to the old residence. The progress of allocating productive land to 
households is still slow because households had been living in the RA since 2011, but until 8/2012, 114 households here had only been allocated land for production for phase 1. After one year, until 8/2013, the remaining 115 households would have land for production when the land allocation is done for phase 2 .

The survey on local people's satisfaction with the allocated productive land area was only conducted at the RA of Hong Thuong commune. The reason is that productive land has been only allocated at the RA of the Hong Thuong commune. Currently, households in the RA of the Hong $\mathrm{Ha}$ commune have not yet been allocated land for production. The resettled households in the Hong Ha commune have not been yet assigned productive land, so the local people confronts many difficulties because they do not have land for economic development. There is no land for production, most of the households have to work as hired labor to get income for the daily living needs of their family. In the RA of the Hong Thuong commune, local people were dissatisfied with the allocated productive land with a mean of 1.31. The reason is that the adjacent boundary of the land parcels has not been clearly defined; allocated field land has not had land banks with water led to the field; The field surface is not flat, making it difficult for local people to produce.

Productive land had been allocated to households in RA of Hong Thuong commune, however, the quality of the land is poor, not suitable for agriculture. The RA of the Hong $\mathrm{Ha}$ commune has not yet been allocated land for production. Therefore, the survey on people's satisfaction with the quality of allocated productive land was only conducted at the RA of Hong Thuong commune. Via the survey results, local people were not satisfied with the quality of productive land in the RA with a mean of 1.08 on the Likert scale. The reason is that most of the productive land here is discolored, the gravels and rocks cannot be cultivated, many areas of land are abandoned and not put into use. The 15 ha of productive land for wet rice often lacks water due to damaged irrigation canals. Production is unstable, the daily living of local people in the RA is very difficult.

\section{Conclusion}

The research process for the current situation of the resettlement arrangement of the $A$ Luoi hydropower project in the Thua Thien Hue province, draws some conclusions as follows: (1) the A Luoi hydropower project has affected 1,907 ha of land in 7 communes and 1,583 households. Among the affected households, there are 285 households with 1.364 inhabitants relocate to implement the project's construction works. (2) local people in the RA of the Hong Ha commune were satisfied with a mean of 4.19 in the Liker scale; the mean of the RA of the Hong Thuong commune was only 1.07. This proves that local people were dissatisfied with the resettlement location. It implies that resettlement arrangements in the Hong $\mathrm{Ha}$ commune are better than those in the Hong
Thuong commune. (3) currently, some facilities and infrastructures have not been implemented as agreed; others have not ensured the quality, which makes local people dissatisfied in both resettlement sites. These limitations cause great difficulties for the life and economic development of the resettled households. Regarding the residential land allocated for resettlement, the households in the RA of the Hong $\mathrm{Ha}$ commune expressed their satisfaction with the mean of 4.5. By contrast, households in the RA of the Hong Thuong commune were dissatisfied with the allocated residential land (mean is only 1.23). The reason is that these households had stable land in their old residence. Furthermore, for the productive land allocated to resettled people, the survey of people's satisfaction was only conducted at the RA of Hong Thuong commune. The reason is that RA at Hong Ha commune has not been allocated land for production. At the RA of the Hong Thuong commune, local people were dissatisfied with the area as well as the quality of the assigned productive land with the assessment scores on the Likert scale of 1.31 and 1.08 , respectively.

From the difficulties and limitations drawn from the research results, some solutions are proposed to improve the resettlement arrangement of the A Luoi hydropower project. Specifically, the budget should be spent to repair and build new infrastructure in resettlement sites. For dissatisfaction with the issue of residential land at the RA of Hong Thuong commune, the government needs to identify specific causes in order to take measures to make local people to feel secure. Besides, the Provincial People's Committee should quickly promote the allocation of productive land to local people in the RA of the Hong $\mathrm{Ha}$ commune, as well as find methods to expand the area and improve the quality of land in productive land areas for resettled households of Hong Thuong commune. Last but not least, the government should make a great effort to timely assist resettlement sites in the difficult moments, ensuring the stable living for local people.

\section{References}

[1] Anh, V., (2019). Hydropower resettlement, more than 10 years still "thirsty" for infrastructure. Retrieved August 25, 2020, from https://doi.org/https://congannghean.vn/kinh-te-xahoi/201809/tai-dinh-cu-thuy-dien-hon-10-nam-vankhat-ha-tang-812079/.

[2] Department of Science and Technology of Thua Thien Hue. (2010). Assessing the current situation and proposing solutions to ensure stability and improve the quality of life for local people in migrant and resettlement areas under irrigation and hydropower projects in Thua Thien Hue.

[3] Hao, V. (2015). Resettlement of hydropower projectsAdverse impacts. Retrieved August 26, 2020, from https://dantocmiennui.vn/tai-dinh-cu-cac-du-anthuy-dien-bai-inhung-tac-dong-nhin-tu-huong-bat- 


\section{loi/25161.html}

[4] IOM (International Organization for Migration), T. U. M. A. (2017). Planned relocation in the context of environmental change in Hoa Binh province, Northern Vietnam: an analysis of household decisionmaking and relocation outcomes.https://publications.iom.int/system/files/p df/planned_relocation_en.pdf

[5] MOIT (Ministry of Industry and Trade). (2016). Summary of migration and resettlement project of Son La Hydropower in 2001-2016. Retrieved August 25, 2020, from https://www.moit.gov.vn/tin-chi-tiet//chi-tiet/tong-ket-du-an-di-dan-tai-đinh-cu-thuy-đienson-la-nam-2001-2016-107655-22.html

[6] Nguyen, L. T., \& Hanh, H. N. (2012). Evaluation of the quality of life in the resettlement areas for hydroelectric plants of Tranh 2 river. Journal of Science and Technology of the University of Danang,
61(12), 100.

[7] Thanh, H. (2018). Migration, resettlement to build irrigation and hydropower works: It is necessary to solve the basis, sustainability. Retrieved August 26, 2020, from https://baodantoc.vn/di-dan-tai-dinh-cude-xay-dung-cac-cong-trinh-thuy-loi-thuy-dien-cangiai-quyet-can-co-ben-vung-8547.htm

[8] The Consultancy on Development (CODE). (2010). Migration, resettlement and life stabilization, environmental protection in hydropower projects in Vietnam. Hanoi, Vietnam.

[9] Thua Thien Hue PPC (Province People's Committee). (2008). Decision 526/QĐ-UBND on 03/03/2008 of Thua Thien Hue Province People's Committee on approval of the overall plan for compensation, support and resettlement, land clearance for the implementation of investment project A of Luoi hydropower plant construction. Thua Thien Hue. 